\title{
Den rumlige vending som ontologisk vending
}

\begin{abstract}
Indledning
I mindst tyve år har begrebet den spatiale vending cirkuleret indenfor samfunds- og humanvidenskaberne, mens det undervejs fra akademisk disciplin til akademisk disciplin har forandret og forskudt sig både indholdsmæssigt- og betydningsmæssigt i forskellige retninger. Mens det er forblevet et ukendt begreb i visse dele af samfunds- og humanvidenskaberne, tages det $\mathrm{i}$ andre grene af samme videnskaber nærmest for givet. Lægger man begrebet ned over samfunds- og humanvidenskaberne som et kort, fremviser den spatiale vending en ujævn og på ingen måde sammenhængende topografi. Det eneste, der kan siges med sikkerhed er, at begrebet overordnet er blevet mere institutionaliseret, og at den spatiale vending med tiden er vedtaget som begreb. Rent bogstaveligt indikerer begrebet en retningsændring, eller ligefrem en u-vending i tematisk orientering. Eller sagt mere præcist sættes den spatiale dimension nu mere eksplicit i fokus i forskellige analytiske og teoretiske ræsonnementer.
\end{abstract}

Det jeg vil fokusere på, belyse og problematisere i denne artikel, er det forhold, at den spatiale vending samtidig er udtryk for en ontologisk vending. Denne ontologiske vending udvider sig som en ontologi med bevagelse som grundlag og fjerner sig mere og mere fra en ontologi med et sedimentert grundlag. Jeg vil med andre ord belyse den spatiale vending som en også filosofisk vending ved som sagt at fokuserer på det ontologiske men samtidig erkende, at denne ontologiske vending også har epistemologiske, politiske og etiske konsekvenser, idet vores handlen i verden står i relation til vores opfattelse af vores tilblivelse (vardande) i verden. Den spatiale vending udgør en vidensproduktion, som kan anvendes til ideologiske og politiske formål, og dette forhold fortjener større opmærksomhed, end det hidtil er blevet tildelt.

Snarere end blot at handle om et fokusskifte, handler det altså om gennem en ændring i synsvinklen (Asplund 1980) at se bevægelse før det sedimentære og altså ikke det sedimentære før det bevægelige (det svarer til at skifte fra at se en ting på nært hold til at studere noget på lang afstand eller omvendt). Det handler om at 
skabe en bevidsthed om, at den spatiale vending også er en ontologisk vending, som har en række effekter i form af en samfundsudvikling, der går i en vis retning med materielle og ideologiske konsekvenser til følge. Jeg vil gøre dette ved at belyse og diskutere en af de seneste spatiale vendinger, nemlig den øgede interesse for rumlighed indenfor management - og organisationsteori.

Artiklen er opdelt i fem dele. I artiklens anden del vil jeg foretage en rekapitulering af den spatiale vending for at indramme fænomenet mere eksplicit med særlig fokus på dimensionen bevagelse-sediment. I artiklens tredje del belyses og diskuteres den øgede interesse for rumlighed indenfor management- og organisationsteorien. I den fjerde del diskuteres organisationen, gennem en analytisk ekstrapolering, ud fra to spatiale tankefigurer - den topografiske og den topologiske - i et forsøg på at overveje nogle forhold for den spatiale vending indenfor management- og organisationsteori og påvise den ontologiske nærhed til radikal politisk teori, her repræsenteret af Giorgio Agambens arbejde. I artiklens afsluttende del opfordres læseren til at reflektere over, at den viden, som følger af den spatiale vending indenfor management- og organisationsteori (men også indirekte indenfor andre akademiske discipliner), ikke bare har frigørende effekter, men også kan anvendes som værktøj til at opnå den modsatte effekt: øget og forfinet kontrol og overvågning, øget magtudøvelse og en afsubjektificering af mennesker.

\section{Den spatiale vending}

Skønt der er mange måder at præsentere den spatiale vending på, findes der næppe en, der dækker det hele. En mulig laveste fællesnævner, som forener dem er, at de alle handler om en søgen efter en aktiv og eksplicit måde at forholde sig til relationen mellem (tids)rummet og samfundet på (og derved udgør de et argument mod en ihærdig kantianisme i form af en opdeling mellem samfund og rum) udtrykt i begrebet rumlighed (spatiality). Der er med andre ord tale om en geografisk synsvinkel, der studerer spatiale helheder, en by til eksempel, ud fra et geografisk helhedssyn - som et diorama - og som ser koplinger, årsagsrelationer, konsekvenser etc., i et nyt lys, der adskiller sig fra studiet af samme by i lyset af en funktionel afgrænsning (som hvis man f.eks. kun studerede byens økonomi).

I samfundsgeografien har rumlighed fået fire hovedbetydninger, som udgøres af tanketraditioner indenfor disciplinen, hvis gennemslagskraft indenfor andre videnskabsdiscipliner har fordelt sig ret ujævnt (Gregory 2009). Den første tanketradition betragter menneskelig rumlighed som udgangspunkt for en eksistentiel tilblivelse i verden, hvor situation og kontekst er afgørende for forståelsen af ver- 
den, og hvor eksistentialisme og fænomenologi udgør den filosofisk klangbund (se f.eks. Pickles 1985). Den anden tanketradition er den strukturel-marxistiske, som bygger på antagelsen af en korrespondens mellem sociale og spatiale strukturer (f.eks. mellem økonomiske strukturelle dimensioner såsom produktion af arbejdskraft og økonomisk pengecirkulation samt spatiale dimensioner såsom arbejdskraftregionen og byens forbrugsrum, se i øvrigt Castells 1977, Massey 1984).

Den tredje tanketradition er den marxistisk agentfokuserede, hvor Henri Lefebvres arbejder (særligt 1991) udgør grundstammen, og hvor rumlighed er ensbetydende med det socialt producerede rum, dvs. både værktøjet til og resultatet af mødet mellem agens og struktur (i strukturteoretisk ånd), eller sagt på en anden måde: en tidsrumlig strukturering af det sociale (Soja 1985). Mange, både i og udenfor den samfundsgeografiske akademiske disciplin, betragter netop Lefebvres The Production of Space (1991) som det arbejde, der mere end noget andet er knyttet til den spatiale vending (Löw 2008). Eftersom Lefebvre opbygger en dialektisk ramme med ambition om at integrere forskellige definitioner af og perspektiver på rum, disker han i praksis op med et helt smørrebrødsbord af anvendelige indfaldsvinkler, hvor den tredelte opdeling mellem spatiale praksisser, oplevede rum og repræsentationer af rum udgør den mest tillempede.

Den fjerde tanketradition bygger på poststrukturalistiske ansatser, med udgangspunkt i særligt Foucault og i mindre grad Deleuze (Doel 1999). Her er rumlighed et udtryk for magt-viden-konstellationers spatiale konstitution, som subjektpositioner produceres i som et udslag af diskurser (Gregory 1994).

Disse fire tanketraditioner kan rent skematisk knyttes til en over tid ført diskussion og problematisering af spatiale begreber (Jessop et al 2008) såsom: stedet forstået som en fænomenologisk fortætning af nære og fjerne relationer (de sene 1980ere); territoriet forstået som udslag af de alt oftere brudte strukturelle magtrelationer i globaliseringens tidsalder med territorialstaten som den synlige taber (tidligt 1990ere); ophævelsen af den konventionelle geografiske skala (lokal, regional, national og global) også indenfor globaliseringens rammer (sene 1990ere). Samt omformuleringen af netvarket som rhizomatisk konstellation (begyndelsen af 00erne). Dette skema afspejler også udmærket den tematiske udvikling indenfor andre akademiske felter som planlægningsteori og arkitektur, der længe har haft det geografiske i fokus.

Jeg vil nu "gå bagom" denne etablerede fortælling om den spatiale vending og betone, at der bag den spatiale vending også findes variationer i og forandringer af standpunkter, der har filosofiske og idéhistoriske udgangspunkter. Den spatiale vending rummer således også en filosofisk vending eller snarere filosofiske forandringer. Disse forandringer udspiller sig skematisk og komprimeret udtrykt inden- 
for to indbyrdes konkurrerende paradigmer - det ene epistemologisk og det andet ontologisk. Jeg vil i det følgende bruge mest plads på at diskutere det ontologiske.

De indbyrdes konkurrerende epistemologiske paradigmer udspringer af Aristoteles og Platons respektive videnskabsteoretiske standpunkter. Mens Aristoteles hævdede, at videnskab først og fremmest udledes af erfaringer baseret på observation af den eksterne verden, beskrev Platon videnskab som evige sandheder, der kun kan nås via fornuften (Herbert \& Bergstedt 2008: 16). Disse to epistemologier, hhv. empirismen og rationalismen går igen i mere eller mindre moduleret form i skismaet mellem positivister og socialkonstruktivister og deres respektive forstålser af rummet som socialt konstrueret eller ej. Samtlige af de ovenfor diskuterede tanketraditioner deler en socialkonstruktivistisk forståelse af rummet. Det ligger så at sige i selve definitionen af rumlighed, Mere interessant og betydningsfuldt er derfor spændingen mellem de to indbyrdes konkurrerende ontologiske paradigmer.

De to ontologiske paradigmer udgår fra de to førsokratiske filosoffer Permenides og Heraklit. Permenides argumenterede for verdens permanente og uforanderlige natur som noget uafhængigt af mennesket, mens Heraklit nærmere argumenterede for altings konstante foranderlighed på trods af den tilsyneladende identiske repetition (Hernes 2008). Disse to ontologier "Permenides væren" (being) og "Heraklits tilblivelse" (becoming) går senere i mere eller mindre moduleret form igen i den vesterlandske metafysiske tradition for at betragte rum som enten udstrækningen af legemer i et absolut rum (efter Descartes) eller blot og bart en sameksistensens orden af relationer, dvs. et relationsbaseret rum (efter Leibniz) (Wang 2000: 119). Samtlige tanketraditioner diskuteret ovenfor udtrykker et skifte fra "Permenides væren" til "Heraklits tilblivelse". Det relationsbaserede rum bliver centralt for den spatiale vending og er "forankret" i en strømmens ontologi (fl̈desontolog $\imath$ ).

Set ud fra et relationsbaseret syn er rummet en proces, og steder er fortætninger af social handlen snarere end et afgrænset område i afstandsrummet i form af et distinkt punkt på et landkort (Graham \& Marvin 2001: 203). Eftersom det spatiale er en proces, er det i sin vorden, som resultat af relationer og materielt indlejrede praksisser (Massey 1999), og kan derfor betegnes som et verbum snarere end et substantiv, eller som artikulationen af relationsbaseret optræden og andre praksisser (Rose 1999). Stedet er således en aktiv hændelse, som udvider sig langs en mangfoldighed af vektorer, der ikke nødvendigvis løber sammen på et og samme fysiske sted i det absolutte rum (Doel 1999: 7). Denne "ontologiske forskydning" giver sig ikke bare udtryk i artikulationen af verber snarere end sub- 
stantiver, men også i udkrystaliseringen af nye termer, som indikerer bevægelse, mangefald, emergens og sameksistens. Som eksempelvis Doreen Masseys (2005) "throwntogetherness", der hurtigt har fået en betydelig indflydelse på skandinavisk samfundsgeografi (se Baerenholdt og Granås 2008). Idet toneangivende geografer (som måske særligt Nigel Thrifft) taler for et relationsbaseret syn på det at "tænke geografisk", har diskursen vundet indflydelse, ikke mindst fordi den harmonerer med og overlapper ontologiske standpunkter indenfor Actor-Network Theory (Jones 2009).

Den spatiale vending kan derfor forstås som et filosofisk standpunkt, der bygger på en strømmens ontologi med fokus på det åbne, det bevægelige, det netværksskabende, og dermed på det topologiske snarere end det topografiske (Jones 2009). Rummet er i konstant bevægelse (Thrift 2006). Denne ontologiske position bevirker, at den spatiale vending sågar overlapper en anden "vending", nemlig "mobilitetsvendingen" (mobility turn), som også strækker sig over flere samfundsvidenskablige og humanistiske discipliner, dog med sociologien som et vist epicentrum. Særligt har John Urry (2000) forsøgt at omdefinere det sociale til noget grundlæggende mobilt snarere end fikseret, og noget som behøver en sociologi, hvis epistemologiske grundsætning stemmer overens med dette. På den anden side af atlanten har Manuel Castells (1996) argumenteret for samme epistemologiske skifte i takt med, at det i følge ham fremvoksende netværkssamfund konstitueres af strømme (rum af strømme) snarere end af det sedimentære (rum af steder). Parallellerne mellem de to vendinger er som sagt omfattende (Adey 2010), men jeg vil her fokusere på, hvordan den spatiale vending implicerer et ontologisk skifte (fra en sedimentær ontologi til en strømmens ontologi) og på, hvordan dette skifte, som akademisk vidensproduktion, kan få ideologiske og politiske konsekvenser. Jeg eksemplificerer ved at vise, hvordan organisation som begreb får ny betydning, idet en rumlig vending folder sig ud indenfor management- og organisationsteorien.

\section{Den spatiale vending indenfor management-og organisationsteori}

Hver rumlig vending indenfor en disciplin kan beskrives som en fortælling med en fortid, nutid og fremtid. Datidssegmentet fokuserer på, hvordan rum som dimension har været fraværende i emnets kanon, nutidssegmentet maler et billede af en rumlig vending, der banker på døren, og fremtidssegmentet giver løfte om en disciplin, der vil øge forståelsen af centrale problemfelter, som disciplinen traditionelt har kæmpet med. Når det gælder management- og organisationsteori (i det 
følgende kun kaldet organisationsteori) portrætteres den klassiske litteratur som rummende et instrumentelt syn på både tid og rum med Taylors videnskabelige managementteori som paradeeksempel (Taylor 1911). Rummet er tidligere blevet betragtet som en absolut container, a priori, manipulerbart og kontrollerbart (Cairns et al 2003). Rummet har traditionelt spillet rollen som en central men uudtalt ingrediens i organisationsteorien - en kontekst, der blev taget for givet (Hernes 2003), og hvis form følger af de forskellige (organisatoriske) handlinger og strategier, der igen følger af en cartesiansk rationalitet (Kornberger \& Clegg 2004). Rum er blevet betraget som noget, der kan designes for at øge produktivitet, kreativitet, de ansattes engagement eller organisationens tiltrækningskraft i et forbrugerperspektiv (Pedersen 2005: 166).

I et historisk perspektiv har der længe været en øget interesse for rumlighed indenfor samfunds- og humanvidenskaberne, mens interessen har haft et betydeligt mindre omfang indenfor organisationsteorien (Dale \& Burell 2008: xi). At interessen nu også har nået denne akademiske disciplin, skal derfor ikke blot forstås som det faktum, at den spatiale vending, som tværvidenskabelig diskurs flytter sig fra emne til emne (ikke sjældent indenfor rammen af en øget interesse for en postmoderne præget interesse for subjektive forestillinger), men også som bevis på, at de studieområder, der har været i centrum, har gennemgået omfattende forandringer, som f.eks. bruddet med de klare grænser mellem arbejde og fritid, udviklingen i informations- og kommunikationsteknologien og de nye netværksbaserede organisationskonstellationer (Hernes 2004: 62-64, Fleming \& Spicer 2004). Selve det faktum, at den (stadigt mere organiserede) verden bliver mere mobil, nødvendiggør en øget sensitivitet vis á vis de spatiale aspekter (Knox et al 2008).

Opdagelsen af, at rum spiller en central rolle for forstålsen af organisationsbegrebet og vice versa (Dale \& Burrell 2008: 4) giver samtidig et løfte om en øget og fordybet forståelse af begrebet. I kraft af en forståelse af rum og sted som analytiske begreber, der indikerer bevægelse, foranderlighed, og mangfoldighed, og som er konstituerede gennem relationer mellem såvel mennesker som artefakter, ophører organisation en gang for alle med at være et, i ontologisk forstand, monolitisk begreb (Hernes 2004: xviii). Man kan i den spatiale vending hente argumenter for at hævde, at organisation snarere skal forstås som et verbum end som et substantiv (Tsoukas \& Chia 2002, Bakken \& Hernes 2006), ligesom det relationsbaserede syn på rum betragter rumlighed som proces, og altså betragter noget, der er, som et verbum. Samtidig opfordrer den spatiale vending, i den version der her er aktuel, os til at betragte organisationer som konfigurationer af multiple og differentierede rum (Halford \& Leonard 2005), som fleksible og dynamiske måder at forholde sig til indramningen af menneskelig handling (Hernes 2004: xviii) og som sociale 
processer, der producerer social og økonomisk orden samt kulturel og historisk betydning (Dale \& Burrell 2008: 141). Følger man Foucault kan organisationer således betragtes som heterotopier (Foucault 1986).

Det er (stadig) svært at få øje på de endelige konturer af den spatiale vending og drage nogle faste konklusioner om, hvilken skikkelse den vil antage indenfor organisationsteorien. To udviklingslinjer kan dog udskilles på nuværende tidspunkt. Den første består af en særlig måde af forholde sig til det spatiale på, nemlig en betoning af materialitetens betydning $i$ et organisationsperspektiv ofte med analytiske forbindelser til spørgsmål vedrørerende organisatorisk dominans og disciplinering af mennesker. Kornberger og Clegg (2003) hæfter sig særligt ved, at den spatiale møblering af organisationens arealer og mødesteder påvirker en given organisationskultur (Se også Zhongyan 2008). Kornberger og Clegg (2004) vender op og ned på den førnævnte cartesianske rationalitet og hævder, at den spatiale og materielle form udformer funktionen. Her nærmer forfatterne sig altså det spatiale gennem en udtalt interesse for arkitektur (Burrell \& Dale 2003, Clegg \& Kornberger 2005) og benytter sig samtidig ofte af Lefebvres forskellige indfaldsvinkler til feltet.

Særligt er Karen Dale (2005) et godt eksempel i denne forbindelse, idet hun hævder, at materialitet rummer en nøgleforståelse af de kontrolmetoder, der anvendes i det organisatoriske liv. Med udgangspunkt i Nigel Thrifts (1996) rumlighedsansats, har hun, i et hverdagsperspektiv og med betoning af praksisser, som udgangspunkt valgt at studere, hvordan materialitet (som i sig selv altid rummer en rumlighed) er indvævet i de forskellige former for social kontrol, ledelsen af en organisationen søger at udøve over de ansatte. Med baggrund i disse studier udvikler Dale selv ansatsen "social materialitet", hvor det sociale og materielle gensidigt realiserer hinanden, med udgangspunkt $i$ bl.a. Lefebvres tese om rummets sociale produktion, hvor rummet forstås som en kombination af materiel og social interaktion. Derefter konstaterer hun, at organisationen i fysisk forstand er forandret. De åbenlyst panoptiske forhold, der kendetegner fabrikkerne, spiller efterhånden kun en marginal rolle. I stedet bliver den post-fordistiske organisation rumligt og socialt arrangeret på nye måder, idet bureaukrati erstattes af decentraliserede og rhizomlignende strukturer, og idet virksomheden, som organisationsforskningen har slået fast, oftest kommer til udtryk i en kontrol over betydningsdannelsen og $\mathrm{i}$ ambitionen om at skabe en vis organisationskultur.

Det materielle forsvinder dog ikke som ingrediens i den organisatoriske ledelse. Energiselskabet, "EnergyCo", kan i den forbindelse bruges som casestudie. EnergyCo var tidligere en traditionel virksomhed, der blev privatiseret samtidig med, at man byggede et nyt hovedkvarter. Hovedkvarteret blev bygget energirig- 
tigt af markedsføringshensyn og indrettet sådan, at interaktion og spontane møder mellem de forskellige afdelinger i virksomheden blev maksimeret. If. Dale virkede bygningens indendørs arkitektur nærmest desorienterende i sin åbenhed - ingen døre, vægge eller barrierer udover de af sikkerhedshensyn strengt nødvendige. Ingen stationære arbejdspladser men i stedet kontorlandskaber trukket ud til den yderste grænse. Åbenheden ødelagde den tidligere kollektive ånd (en omfattende fritstillelse af mennesker og nyansættelser af andre bidrog yderligere til dette), hvilket påvirkede alle ansatte og bevirkede, at de fremover forstod deres primære relation til arbejdspladsen som den, de havde til arbejdsgiveren med karrieren som apeks, sigtepunkt. En ny virksomhedskultur indfandt sig, i hvilken den store arkitektoniske åbenhed og manglen på synlige grænser mellem de forskellige afdelinger af de ansatte først og fremmest blev tolket som en mulighed og mindre som et kontrol- og overvågningsrum (hvilket det dog naturligvis også samtidig var).

Den anden udviklingslinje fokuserer på rum som et analytisk begreb, der (bedre end alternative begreber som f.eks. kontelest) indfanger den kompleksitet og mangetydighed, der præger dagens organisatoriske landskaber. Her bliver rum indgang til en forståelse af alt, der kan repræsenteres - strukturer, fænomener, processer - eftersom alt, der kan repræsenteres, kan repræsenteres rumligt (Hernes 2004). Management og organisering bliver her bløde teknologier i en kapitalistisk symboløkonomi (Thrift 2005), som bør analyseres gennem en rumlig semiotik, der tager hensyn til organisatoriske, materielle og repræsentationsmæssige aspekter (Pedersen 2005; 56, 162).

Der er her tydelige tegn på, at der sættes et ontologisk spørgsmålstegn ved dominerende tankelogikker, ikke bare indenfor organisationsteorien men ved vestlig metafysik $i$ det hele taget $i$ form af en opklaring af og en problematisering af definitionen af "organisation" samt en diskussion, der omhandler organisationers grænser og organisatorisk grænsedragning. Tor Hernes (2004: xix) diskuterer organisatoriske grænser og distinktioner, ordensskabelse og tærskler, mens Jackie Ford og Nancy Harding (2004) gennem en læsning af Lefebvres konceptualisering af rum og sted konstaterer, at den konstruerede ontologiske distinktion mellem en organisation og dens medlemmer imploderer, hvorfor organisation derfor kun kan artikuleres gennem organisationsmedlemmernes kropslighed og performative praksisser.

Et bidrag indenfor den anden udviklingslinje, hvor en mere udtalt ontologisk diskussion sættes igennem, finder man hos Hannah Knox et al (2008), der med udgangspunkt i Castells teorier om Spaces of Flow og Actor Network. Theory, betragter "organisering", som det spinkle [eller revnede?] udfald af måder at skabe orden på, som aktualiseres af og gennem komplekse heterogene sammenførte og sam- 
menkoblede opstillinger af materiale, mennesker og teknologi. Ved at følge og undersøge de socio-teknologiske mønstre, rutiner, og relationer, der tilsammen udgør en anonymiseret lufthavn et sted i Storbritannien, noterer de sig, hvordan et deleuzeiansk "intensivt rum" (efter Massumi 2002) udfolder sig, hvor grænserne mellem det virtuelle og det reelle udviskes. Særligt gør den digitale informationsteknologis kontrol over strømmen af mennesker og artefakter, hvor individer reduceres til "divider" (Deleuze 1995: 180) via digitale forbehold og restriktioner, noget ved den ontologiske definition af menneske. Og "rummet" har en delagtighed i dette (Knox et al 2008: 885, understreget i originalen):

Today, media and surveillance technologies in combination with various forms of expert systems fuel novel dreams of order(ing) by means of smart buildings, automation, virtuality and remote control. Space is the medium of their co-evolution, but space in organizations such as airports is no longer a well-bounded stable container, and its 'contents' no longer containable or secure in terms of the categories and expectations of a mundane ontology. Airport-organization is increasingly more akin to a heterotopia or fractal of 'virtual' and 'real' topoi. Circumscribed and conjoined by hybrid networks of borders and boundaries this heterotopia inevitably introduces new limits and transgressions as the airport strives to fulfil its mission to bring the world closer.

Det lader sig altså gøre at indlæse både en ontologisk vending og en vidensproduktion, der tillader nye måder at forstå verden på, i den spatiale vending indenfor organisationsteori, men rimeligvis også i spatiale vendinger indenfor andre discipliner og i andre sammenhænge. Denne ontologi kan naturligvis udgøre en emanciperende og selvstændiggørende kraft, men den kan også anvendes til det modsatte og dermed bidrage til en forøget viden om magtudøvelse, politisk undertrykkelse og reduktion af politiske og subjektive rettigheder. Den spatiale vending rummer en strømmens ontologi, som ikke er immun overfor politisk brug. Det er nødvendigt at problematisere dette forhold og sidestille det med en diskussion af, hvorvidt vi kan forstå magt ud fra en strømmens logik, og hvordan "organisering" i den sammenhæng bliver begrebsliggjort.

\section{At betragte organiseringen af verden topografisk og topologisk}

Ved at sidestille to spatiale tankefigurer - den topografiske og den topologiske, vil jeg nu gøre nogle overvejelser over, hvordan den spatiale vending indenfor organisationsteorien hænger sammen med det topologiske syn på magt og magtudøvelse. Her anvender jeg først og fremmest Giorgio Agambens idé om magt som topo- 
logisk snarere end topografisk, og hævder forsøgsvist, at topologisk magtudøvelse er baseret på en strømmens ontologi på en mere udtalt måde end topografisk magtudøvelse, hvor den sedimentære grænse har større betydning.

Grænsedragningens institutionalisering afslører det moderne projekts dominerende ontologi udtrykt i former som ejendomsret og territoriallogik (Latour 1993, Netz 2004). Kornberger og Clegg (2003) sporer den ontologiske distinktion mellem en organisation og dens omverden i en europæisk forestilling, som strukturerer spatiale relationer ud fra en indenfor/udenfor-tankemodel. Denne tankemodels struktur fremviser en enkel grænse mellem det, som er inkluderet, og det som ikke er det. I skematisk betydning er organisationen traditionelt blevet tildelt rollen som et ordensskabende apparat, et middel til at opnå en stabil, forudsigelig og sikker ekstern verden, eller alternativt et ordensskabende apparat, der skaber en intern verden og beskytter den fra kaos udenfor.

Denne organisationsmodel er topografisk og er del af et velforankret tankegods i den vestlige idéhistorie (f.eks. i Hobbes distinktion mellem naturtilstanden og Leviathan), som kan spores historisk via myten om Romulus og Remus til Aristoteles skelnen mellem polis og oikos (Diken \& Bagge Laustsen 2006). Denne topografiske ontologi medfører en enten-eller situation, hvor det er umuligt at befinde sig udenfor og indenfor samtidig; En situation der på sin side har skabt et normskabende system af dikotomier (Haraway 1991), som igen på sin side kendetegner organiseringen af samfundet. I en topografisk læsning er det således umuligt både at være indenfor og udenfor Roms mure, eller at være både indenfor og udenfor den pigtråd, som indhegner et lukket rum (Netz 2004). Man er medlem eller ikke-medlem.

Kornberger og Clegg (2003: 78) hævder dog, at rummets iboende kompleksitet (sådan som det fremstilles i den spatiale vending) og den rolle, det har, som bærer af modsigelse, forpligter os til at udfordre den etablerede indenfor/udenfor orden. Dette sker netop i det mellemrum, som en topografisk læsning ikke levner rum til, men som har fået en del opmærksomhed og er blevet givet indhold af bl.a. Foucault i dennes lancering af heterotopiabegrebet og af Deleuze i hans anvendelse af begrebet fold (1993).

Kornberger og Clegg (2003: 81) hævder at:

Both concepts allow us to think space socially: they question the contemporary obsession with order; they rethink the simple but powerful inside/outside division that still informs spatial reflections widely, as the fold and heterotopia are both spatial and social concepts that...question the modernist obsession in architecture, as well as in management, with order and control. 
Det er særligt folden, som i Kornberger og Cleggs (2003: 84) fremstilling forandrer forholdet mellem indenfor og udenfor. Folden bliver et rum for passage eller en tærskel, hvor valget mellem orden og uorden og indenfor og udenfor endnu ikke er blevet gjort; Det ontologiske valg er ugjort. Denne position eller zone af ubestemthed leder tankerne hen på Agambens (1998) kritik af det udgangspunkt, den vestlige metafysik, og i forlængelse heraf dens politiske filosofi, tager i den topografiske tankemodel. Et udgangspunkt som bl.a. har resulteret i opfattelsen af en politisk suverænitet, der ses som noget iboende Leviathan og adskilt fra naturtilstanden. Carl Schmitt, som med sin påstand om, at suverænen er den kraft i samfundet, der kan sætte sig udenfor loven og udråbe undtagelsestilstanden, fra norm/ undtagelse til norm/ undtagelse (Schmitt 1985), bliver stående som repræsentant for denne modernistisk topografiske ontologi, som Agamben stiller spørgsmålstegn ved. Snarere er det sådan, hævder Agamben (2005: 23):

In truth, the state of exception is neither external nor internal to the juridical order, and the problem of defining it concerns precisely a threshold, or a zone of indifference, where inside and outside do not exclude each other but rather blur with each other.

Forholdet mellem norm og undtagelse, mellem yderside og inderside er som følge heraf topologisk, eftersom de er forskellige sider af samme proces, og virkelig suveræn magt er følgelig kapaciteten til at skabe denne ubestemthed og samtidigt kunne skjule den (Agamben 1998: 37):

\footnotetext{
The state of exception is thus not so much a spatiotemporal suspension as a complex topological figure in which not only the exception and the rule but also the state of nature and law, outside and inside, pass through one another. It is precisely this topological zone of indistinction, which had to remain hidden from the eyes of justice, that we must try to fix under our gaze.
}

Agambens aspektskifte, hvor det, som i politisk filosofi betragtes i et topografisk perspektiv, nu i stedet undersøges topologisk, har det resultat, at verden fremtræder $i$ et andet lys end den velkendte lyssætning (De Cauter 2004). Frem for et fokus på skikkelse, overflade og relief ligger fokus i stedet på funktionalitet, relationer og sammenkoblinger (Murdoch 2006: 12). Når inderside og yderside befinder sig i en topologisk relation som et møbiusbånd, bliver det umuligt at betragte organisation som et citadel af orden baseret på sedimentær grænsedragning. I stedet bliver organisation en tærskel mellem uorden og orden (Bos 2005: 18-19). Denne tærskel eller zone af ubestemthed er generisk relationsbaseret og er derfor kompatibel 
med forståelsen af rummet som et verbum og noget, der hele tiden sker. Men hvis vi studerer (det organiserede) rum eller (den spatiale) organisation topografisk som et containerlignende produktionsrum, ser vi ikke disse topologiske vrid (Gregory 2007).

Clegg et al (2006: 29-30) tager et sådant eksempel op, når de argumenterer for, at alle organisationer har en iboende kapacitet til at kunne forvandles til totale institutioner (Goffman 1961), sådan som det var tilfældet med koncentrationslejren under anden verdenskrig. Men fordi man har betragtet organisationer som topologiske citadeller af orden med tydelige grænser, er dette ikke blevet noteret indenfor organisationsteorien. I et topografisk-ontologisk syn på organisationer befinder Auschwitz og Guantánamobasen sig langt fra hinanden på grund af det omgivende relief/kontekst (i det ene tilfælde befinder lejren sig i en totalitær - men formelt demokratisk - statsmagts regi, i det andet tilfælde er der tale om en lejr i en demokratisk statsmagts regi). I et topologisk-ontologisk syn på organisationer befinder Auschwitz og Guantánamobasen sig betydeligt nærmere hinanden som biopolitiske produktionsrum for det nøgne afsubjektificerede liv (Agamben 2004).

De "ekstreme eksempler" på organisatorisk undertrykkelse er således ikke undtagelsestilfælde, der kan afvises som ikke længere relevante i en topologisk ontologi, men er snarere eksempler på høje koncentrationer af generiske egenskaber, som findes i alle organisationsformer (Clegg et al 2006: 143) og i forlængelse af en iboende egenskab i det moderne projekt (en argumentationsrække, som ligeledes er blevet fremført af Bauman 1989). Rumsopfattelsen, valget at forstå rum som en proces, et verbum, som relationsbaseret, impliceres af og implicerer et ontologisk standpunkt, der kan beskrives topologisk og fokuserer på strøm, og hvor grænsedragningen per definition er bevægelig. At betragte rummet som et verbum, sammenkoblet gennem bevægelse og forskydninger af grænser, er et virkningsfuldt udgangspunkt for at kunne studere magt udefra, hvilket Agambens gennembrud indenfor samfundsvidenskabelig og humanistisk forskning kan ses som en indikation af. At det i særdeleshed er kritiske studier af migration og andre tematiske områder, hvor bevægelse står i centrum, Agamben først og fremmest anvender som referencekilder, er sigende i denne sammenhæng (Ek 2006a). Agamben "skærer" virkeligheden på en anden måde end konventionel magtforskning gør, også selvom han kan siges at gøre dette ud fra en dikotomi, som i sig selv er fast forankret i en modernistisk tanketradition. 


\section{Behovet for at reflektere over den spatiale vendings politiske potentiale}

Målet med denne artikel har været at belyse den spatiale vending og problematisere ideen om, at den blot skulle være en akademisk proces, der sætter rummet og det geografiske mere i centrum, ved at vise, at den samtidig er en akademisk proces, der implicerer en ontologisk vægtforskydning fra en sedimentær ontologisk postion til en mere rendyrket strømsontologisk position.

Jeg indledte med at sammenfatte hovedpunkterne $\mathrm{i}$ den spatiale vending indenfor den samfundsgeografiske idétradition i fire tankeretninger, som samtidig i en vis forstand bryder med det kantianske skel mellem "samfund/det sociale" og "rum" (indfanget i begrebet "rumlighed"). Jeg gik siden videre og argumenterede for, at denne spatiale vending også rummer en ontologisk overgang fra synet på rum som noget, der "er" (varende), til noget som "bliver til", dvs. er en proces (vordende), og at rummet snarere bør betragtes som et verbum end et substantiv. I et tredje analytisk skridt hævdede jeg videre, at denne ontologiske overgang (skematisk betragtet) ligeledes indikerer en overgang til en strømmens ontologi fra et mere stillestående, sedimentært syn på verdens beskaffenhed. Nye begreber og fokus på aspekter som forandring, bevægelse, det fluide, sammenkoblinger etc. danner den spatiale vendings terminologi.

Jeg fortsatte $\mathrm{i}$ artiklens tredje del med at vise og eksemplificere, hvordan samme grundlæggende ontologier genfindes indenfor den spatiale vending, der for forholdsvis nyligt er blevet udviklet indenfor organisationsteorien. En af de primære konsekvenser af dette er, som jeg ser det, at selve definitionen af "organisation" gradvist får nyt indhold og i lighed med definitionen af rum i stigende grad betragtes som et verbum, en proces, noget som hele tiden befinder sig i et vordende og i forandring (selv indenfor rammerne af den deleuzianske repetition). Organisation ses ikke længere som et (sedimentært) citadel af orden men som noget skiftende, flydende, procesagtigt. Den organisatoriske grænsedragning bliver mindre central til fordel for den type af organisatorisk grænsedragning, der sættes indenfor rammerne af dannelsen af orden af mennesker, artefakter, immaterielle tegnsystemer og materiel og digital teknologi.

I artiklens fjerde afsnit trak jeg de to spatiale tankefigurer frem, hhv. den topografiske og den topologiske (den sidste repræsenteret af Agamben) for at vise, at den spatiale vending med sin base i et procesperspektiv og en strømmens ontologi er kompatibel med et kritisk, topologisk funderet syn på magt. Ud fra dette betragtet er det nærliggende at hævde, at den spatiale vending med sit relationsbaserede syn på rummet kan beriges af og i sig selv beriger eksempelvis Agambens topologiske forståelse af magt og magtanvendelse. Noget jeg også tidligere har 
argumenteret for (Ek 2006a). Her eksisterer naturligvis et oplysende og frigørende potentiale.

Men det er ikke hele billedet. I en anden sammenhæng (Ek 2006b) har jeg kommenteret en anden nyligt indledt rumlig vending, denne gang indenfor medieog kommunikationsstudier. Her hævdede jeg, at en vidensproduktion indenfor medie- og kommunikationsforskning, influeret ikke mindst af en relationsbaseret rumforståelse, også må reflektere over, hvordan produktionen af viden også kan anvendes af forskellige regimer i forskellige magtudøvelsessammenhæng, Selv her kunne man iagttage et skifte i fokus henimod strøm og bevægelse, eksempelvis mobile medier, under den prøvende overskrift "Geographies of Communication" (Jansson \& Falkheimer 2006). En vidensproduktion som forholder sig til rumlighed, medie og kommunikation og bevægelse kunne meget vel tænkes at være interessant for et regime med interesse $i$ at skabe et medie- og kommunikationsklima, som fremmer den herskende orden (Berlusconis magtregime ligger i den sammenhæng lige for), og som ansvarsfulde intellektuelle (Said 1995) er vi nødt til at tage denne mulighed op til diskussion.

Det samme gør sig gældende for det intellektuelle projekt, der går under navnet "den spatiale vending" eksempelvis indenfor organisationsforskningen (men naturligvis også andre discipliner). En øget forståelse af, hvordan menneskestrømme kanaliseres og kontrolleres i lufthavne, ved grænsekontrolposter, i byer, ud fra en relationsbaseret rumopfattelse og en strømmens ontologi kan også komme et totalitært magtapparat til gode, eller et formelt demokratisk magtapparat, som vil hæmme, kanalisere og stratificere immigrationen til og forflytningen indenfor et territorium. Deleuze og Guattaris tekster (1988) om det glatte og stribede rum, nomaden og krigsmaskinen har f.eks. haft en betydende indflydelse på den amerikanske krigsmaskines tænketanke (Ek 2000), for nu at tage et nærliggende eksempel. Deleuze mente helt sikkert, at hans tekster bare var filosofi og intet andet end filosofi (Ek 2006a), men helt så enkelt er det ikke. Tekstproduktion, som søger en øget forståelse af mobile, relationsbaserede magt-, overvågnings-, og kontrolpraktikker, kan anvendes til at forfine samme praksisser, og det er noget, der bør diskuteres i større grad, end hvad der hidtil har været tilfældet.

Oversat fra svensk. af

Astrid Nonbo Andersen 


\section{Litteratur}

Adey, Peter (2010): Mobility, London: Routledge.

Agamben, Giorgio (1998): Homo Sacer. Sovereign Power and Bare Life, Stanford: The Stanford University Press.

Agamben, Giorgio (2004): “Bodies Without Words: Against the Biopolitical Tatoo”, German Law Journal, vol. 5, nr. 5, s. 168-169.

Agamben, Giorgio (2005): State of Exception, Chicago: The University of Chicago Press. Asplund, Johan (1980): Om undran inför sambället, Lund: Argos.

Bakken Tore \& Hernes, Tor (2006): "Organizing is Both a Verb and a Noun: Weick Meets Whitehead", Organization Studies, vol 27, nr 11, s. 1599-1616.

Bauman, Zygmunt (1989): Modernity and the Holocaust, Ithaca: Cornell University Press.

Bos, René ten (2005): "Giorgio Agamben and the Community Without Identity", The Sociological Review, vol. 53, nr. 1, s. 16-29.

Burrell, Gibson \& Dale, Karen (2003): "Building Better Worlds? Architecture and Critical Management Studies" i Mats Alvesson \& Hugh Willmott (red.), Studying Management Critically, Sage: London, s. 177-196.

Bærenholdt, Jørgen Ole \& Granås, Brynhild (red.)(2008): Mobility and Place: Enacting Northern Peripheries, Aldershot: Ashgate.

Cairns, George; McInnes, Peter \& Roberts, Phil (2003): “Organizational Space/Time: From Imperfect Panoptical to Heterotopian Understanding", Ephemera, vol. 3, nr. 2, s. 126-139.

Castells, Manuel (1977): The Urban Question, London: Edward Arnold.

Castells, Manuel (1996): The Rise of the Network Society, Oxford: Blackwell.

Clegg, Stewart R., Courpasson, David and Phillips, Nelson (2006): Power and Organizations, London: Sage.

Clegg, Stewart \& Kornberger, Martin (2005): “Organising Space”, i Stewart R. Clegg \& Martin Kornberger (red.), Space, Organizations and Management Theory, Malmoe \& Copenhagen: Libris \& Copenhagen Business School Press, s. 143-162.

Dale, Karen (2005): 'Building a Social Materiality: Spatial and Embodied Politics in Organizational Control", Organization, vol. 12, nr 5, s. 649-678.

Dale, Karen \& Burrell, Gibson (2008): The Spaces of Organisation and the Organisations of Space. Power, Identity and Materiality at Work, Houndmills: Palgrave Macmillan.

De Cauter, Lieven (2004): The Capsular Civilization. On the City in the Age of Fear, Rotterdam: NAi Publishers.

Deleuze, Gilles (1993): The Fold: Leibniz, and the Baroque, Minneapolis: University of Minnesota Press.

Deleuze, Gilles (1995): Negotiations, 1972-1990, New York: Columbia University Press.

Deleuze, Gilles \& Guattari, Félix (1988): A Thousand Plateaus. Capitalism and Schizophrenia, London: The Athlone Press.

Diken, Bülent \& Lausten Bagge, Carsten (2006): “The camp”, Geografiska Annaler B: Human Geography, vol. 88, nr. 4, s. 443-452.

Doel, Marcus A (1999): Poststructuralist Geographies. The Diabolical Art of Spatial Science, Edin- 
burgh:

Edinburgh University Press.

Ek, Richard (2000): “A Revolution in Military Geopolitics?”, Political Geography, vol. 19, nr. 7, s. 841-874.

Ek, Richard (2006a): "Giorgio Agamben and the Spatialities of the Camp", Geografiska Annaler B: Human Geography, vol. 88, nr. 4, s. 363-386.

Ek, Richard (2006b): "Media Studies, Geographical Imaginations and Relational Space", i Jesper Falkheimer \& André Jansson (red.), Geographies of Communication. The Spatial Turn in Media Studies, Göteborg: Nordicom, s. 45-66.

Fleming, Peter \& Spicer, André (2004) "'You Can Checkout Anytime, But You Can Never Leave': Spatial Boundaries in a High Commitment Organization”, Human Relations, vol. 57, nr. 1, s. 75-94.

Ford, Jackie \& Harding, Nancy (2004) "We Went Looking for an Organization but Could Find Only the Metaphysics of its Presence”, Sociology, vol. 38, nr. 4, s. 815-830.

Foucault, Michel (1986): "Of Other Spaces”, Diacritics, vol. 16, nr. 1, s. 22-27.

Goffman, Erving (1961): Asylum. Essays on the Social Situation of Mental Patients and Other Inmates, New York: Doubleday.

Graham, Steve \& Marvin, Simon (2001): Splintering Urbanism. Networked Infrastructures, Technological Mobilities and the Urban Condition, London: Routledge.

Gregory, Derek (1994): Geographical Imaginations, Oxford: Blackwell.

Gregory, Derek (2007): "Vanishing Points: Law, Violence, and Exception in the Global War Prison”, i Derek Gregory \& Allan Pred (eds.), Violent Geographies: Fear, Terror and Political Violence, New York: Routledge, s. 205-236.

Gregory, Derek (2009): "Spatiality” i Derek Gregory et al (eds.), The Dictionary of Human Geography, $5^{\text {th }}$ Editon, Oxford: Blackwell, s. 715-717.

Halford, Susan \& Leonard, Pauline (2005): "Place, Space and Time: Contextualizing Workplace Subjectivities”, Organization Studies, vol. 27, nr. 5, s. 657-676.

Haraway, Donna (1991): Simians, Cyborgs, and Women: The Reinvention of Nature, London: Free Association Books.

Herbert, Anna \& Bergstedt, Bosse (2008): Kunskapen och spräket-om pedagogiken, texten och bjärnan, Malmö: Liber.

Hernes, Tor (2003): "Organization as Evolution of Space" i Barbara Czarniawska \& Guje Sevón (red.), The Northern Lights - Organization Theory in Scandinavia, Malmö: Liber, s. 267-289.

Hernes, Tor (2004): The Spatial Construction of Organization, Amsterdam: John Benjamins Publishing Company.

Hernes, Tor (2008): Understanding Organization as Process. Theory for a Tangled World, London: Routledge.

Jansson, André \& Falkheimer, Jesper (2006): “Towards a Geography of Communication” i Jesper Falkheimer \& André Jansson (red.), Geographies of Communication. The Spatial Turn in Media Studies, Göteborg: Nordicom, s. 9-25. 
Jessop, Bob; Brenner, Neil \& Jones, Martin (2008): "Theorizing Sociospatial Relations", Environment and Planning D: Society and Space, vol. 26, nr. 3, p. 389-401.

Jones, Martin (2009): "Phase Space: Geography, Relational Thinking, and Beyond”, Progress in Human Geography, vol 33, nr. 4, s. 487-506.

Knox, Hannah; O'Doherty, Damian; Vurdubakis, Theo \& Westrup, Chris (2008): "Enacting Airports: Space, Movement and Modes of Ordering", Organization, vol. 15, nr. 6, s. 869888.

Kornberger, Martin \& Clegg, Stewart (2003): "The Architecture of Complexity", Culture and Organization, vol. 9, nr. 2, s 75-91.

Kornberger, Martin \& Clegg, Stewart R (2004): "Bringing Space Back In: Organizing the Generative Building”, Organization Studies, vol. 25, nr. 7, s. 1095-1114.

Latour, Bruno (1993): We Have Never Been Modern. Cambridge: Harvard University Press.

Lefebvre, Henri (1991): The Production of Space, Oxford: Blackwell.

Löw, Martina (2008): " The Constitution of Space: The Structuration of Space Through the Simultaneity of Effect and Perception", European Journal of Social Theory, vol. 11, nr. 1, s. 25-49.

Massey, Doreen (1984): Spatial divisions of labor: Social Structures and the Geography of Production, New York: Methuen.

Massey, Doreen (1999): "Space of Politics", i Doreen Massey, John Allen \& Pierre Sarre (red.), Human Geography Today, Cambridge: Policy Press, s. 279-294.

Massey, Doreen (2005): For Space, Sage: London.

Massumi, Brian (2002): Parables for the Virtual: Movement, Affect, Sensation, Durham: Duke University Press.

Murdoch, Jonathan (2006): Post-Structuralist Geography. A Guide to Relational Space, London: Sage.

Netz, Reviel (2004): Barbed Wire. An Ecology of Modernity, Middletown: Wesleyan University Press.

Pedersen, Søren Buhl (2005): Making Space: An Outline of Place Branding, Copenhagen: Copenhagen Business School.

Pickles, John (1985): Phenomenology, Science and Geography: Spatiality and the Human Sciences, Cambridge, Cambridge University Press.

Rose, Gillian (1999): "Performing Space”, i Doreen Massey, John Allen \& Pierre Sarre (red.), Human Geograpby Today, Cambridge: Policy Press, s. 247-259.

Said, Edward (1995): Den intellektuelles ansvar, Stockholm: Bonnier Alba essä.

Schmitt, Carl (1985): Political Theology: Four Chapters on the Concept of Sovereignty, Cambridge: MIT Press.

Soja, Edward W (1985): “The Spatiality of Social Life: Towards a Transformative Retheorisation”, i Derek Gregory \& John Urry (red.), Social Relations and Spatial Structures, London: Macmillan, s. 90-122.

Taylor, Frederick W. (1911): Principles of Scientific Management, New York: Harper Collins.

Thrift, Nigel (1996): Spatial Formations, Sage: London. 
Thrift, Nigel (2005): Knowing Capitalism, Sage: London.

Thrift, Nigel (2006): "Space”, Theory, Culture \& Society, vol. 23, nr. 1, s. 139-146.

Tsoukas, Haridimos \& Chia, Robert (2002): ”On Organizational Becoming: Rethinking Organizational Change", Organization Science, vol. 13, nr. 5, s. 567-582.

Urry, John (2000): Sociology Beyond Societies: Mobilites for the Twenty-First Century, London: Routledge.

Urry, John (2007): Mobilities, London: Sage.

Wang, Ning (2000): Tourism and Modernity. A Sociological Analysis, Amsterdam: Pergamon.

Zhongyuan, Zhang; Spicer, André \& Hancock, Philip (2008): "Hyper-Organizational Space in the Work of J. G. Ballard", Organization, vol 15, nr 6, s. 889-910. 